\title{
PELATIHAN DAN PEMANFAATAN LITERASI INFORMASI E-WAKAF UNTUK PENGELOLAAN ADMINISTRASI WAKAF SEBAGAI DUKUNGAN LAYANAN PRIMA PEJABAT PEMBUAT AKTA IKRAR WAKAF
}

Training of E-Wakaf Information Literacy For Wakaf Administration Management As Support For Officer of Ikrar Wakaf

\author{
Amiq Fahmi ${ }^{1}$, Edi Sugiarto ${ }^{2}$ \\ ${ }^{1}$ Program Studi Sistem Informasi, Fakultas Ilmu Komputer, Universitas Dian Nuswantoro \\ ${ }^{2}$ Program Studi Teknik Informatika, Fakultas Ilmu Komputer, Universitas Dian Nuswantoro \\ Jl. Imam Bonjol 207, Semarang 50131 Telp. (024) 3517261, Faks. (024)3569684 \\ E-mail: ${ }^{1}$ amiq.fahmi@dsn.dinus.ac.id, ${ }^{2}$ edi.sugiarto@dsn.dinus.ac.id
}

\begin{abstract}
Abstrak
Tertib hukum dan tertib administrasi sangatlah penting untuk melindungi harta benda wakaf. Paradigma baru pengelolaan wakaf, dimana aspek legalitas formal menjadi unsur penting dalam pengamanan harta benda wakaf. Pejabat Pembuat Akta Ikrar Wakaf (PPAIW) adalah pejabat berwenang untuk membuat Akta Ikrar Wakaf. PPAIW merupakan salah satu unsur penting dari wakaf, dan melekat sebuah peran, tugas dan wewenang dalam melayani, menyelesaikan, dan mengamankan harta benda wakaf, baik secara administratif atau lainnya. Namun demikian, PPAIW sampai dengan saat ini dinilai belum menunjukkan performa yang ideal dan tidak memiliki kemampuan profesional dalam mencatat dan mengelola administrasi harta benda wakaf di lingkungan kerjanya. E-Wakaf adalah sistem berbasis komputer yang dikembangkan untuk pengelolaan dan pencatatan data administratif harta benda wakaf. Tujuan dari program kemitraan masyarakat pelatihan dan pemanfaatan literasi komputer dan informasi e-Wakaf adalah untuk mendukung layanan prima PPAIW dalam mengelola data administrasif harta benda wakaf di lingkungan kerjanya. Metode pelatihan dan praktikum komputer di laboratorium dipilih dalam transfer skill dan pengetahuan pengelolaan wakaf menggunakan aplikasi e-Wakaf. Hasil akhir pelatihan dan pemanfaatan literasi informasi e-Wakaf adalah PPAIW memiliki data aset wakaf yang akurat dan kredibel, dan PPAIW dapat meningkatkan kinerja dan kualitas pelayanan prima kepada masyarakat.
\end{abstract}

Kata Kunci : E-wakaf, literasi komputer dan informasi, pelatihan, pelayanan prima, PPAIW.

\section{PENDAHULUAN}

Dalam penjelasan Undang-Undang Nomor 41 Tahun 2004 Tentang Wakaf, dijelaskan bahwa praktik wakaf yang terjadi dalam kehidupan masyarakat belum sepenuhnya berjalan tertib dan efisien sehingga dalam berbagai kasus harta benda wakaf tidak terpelihara sebagaimana mestinya, terlantar atau beralih ke tangan pihak ketiga dengan cara melawan hukum. Untuk menciptakan tertib hukum dan administrasi wakaf guna melindungi harta benda wakaf, maka perbuatan hukum wakaf wajib dicatat dan dituangkan dalam akta ikrar wakaf dan didaftarkan serta diumumkan yang pelaksanaannya dilakukan sesuai dengan tata cara yang diatur dalam peraturan perundangundangan yang mengatur mengenai wakaf dan harus dilaksanakan (Republik Indonesia, 2004).

Pejabat Pembuat Akta Ikrar Wakaf (PPAIW) adalah pejabat (orang yang diberikan tugas dan kewenangan yang sah menurut hukum) yang ditetapkan oleh Menteri Agama Republik Indonesia 
untuk membuat Akta Ikrar Wakaf. PPAIW merupakan salah satu pilar penting dalam perwakafan nasional. Kedudukan PPAIW secara administratif sangat penting dan strategis, yaitu untuk kepentingan pengamanan harta benda wakaf dari sisi hukum, khususnya dari sengketa dan perbuatan pihak ketiga yang tidak bertanggung jawab. Namun demikian banyak PPAIW yang tidak memiliki kemampuan profesional dalam mencatat dan mengelola administrasi harta benda wakaf di lingkungan kerjanya (Kementerian Agama Republik Indonesia et al., 2013).

Perguruan Tinggi (PT) adalah salah satu lembaga yang diharapkan berperan aktif dalam knowledge transfer ke masyarakat dalam bentuk diseminasi hasil penelitian yang telah dilakukan. Penelitian dengan judul "Perencanaan Strategis Sumber Daya Informasi Manajemen Aset Wakaf (E-Wakaf) Berbantuan Sistem Informasi Geografis" (Fahmi and Sugiarto, 2015; Fahmi and Sugiarto, 2016) dan dilanjutkan dengan penelitian dengan judul "E-Wakaf Sebagai Model Pengaman Aset Wakaf Dan Untuk Mengidentifikasi Wakaf Strategis Produktif Guna Pemetaan Potensi Ekonomi, Pemberdayaan Dan Pengembangan Wakaf" (Fahmi and Sugiarto, 2017) telah menghasilkan purwarupa berupa perangkat lunak sistem e-Wakaf yang sudah siap untuk diimplementasikan. Diseminasi dari hasil penelitian ini merupakan suatu kegiatan yang ditujukan kepada kelompok target/individu agar memperoleh informasi, kemudian timbul kesadaran, serta menerima, dan pada akhirnya memanfaatkan informasi tersebut sehingga terdapat kesepakatan untuk melaksanakan inovasi. E-Wakaf dikembangkan untuk pengelolaan dan pencatatan administratif harta benda wakaf dalam jangka panjang dan merupakan suatu rangkaian sistem yang terpadu dengan dukungan sistem informasi geografis yang dapat digunakan secara efektif untuk mengelola (menghimpun, menyimpan, memproses, memperbaiki), mengontrol dan mengendalikan aset wakaf sampai dengan titik objek wakaf melalui penginderaan jauh keruangan dan menghasilkan informasi baik berupa laporan, dokumen, grafik, gambar peta dan keluaran lainnya yang relevan (Fahmi and Sugiarto, 2015; Fahmi and Sugiarto, 2016; Fahmi and Sugiarto, 2017).

Pelatihan pemanfaatan literasi informasi e-wakaf ini merupakan langkah penyebaran inovasi peneliti yang telah direncanakan, diarahkan, dan dikelola dengan baik, efektif dan efisien yang bertujuan untuk membantu PPAIW KUA Kota Semarang. PPAIW merupakan kunci dari seluruh jabaran administratif perwakafan nasional dan diantara tugas-tugas pokoknya adalah menyediakan administrasi wakaf dan melayani keperluan calon wakif yang akan mewakafkan sebagian harta bendanya dengan baik dan profesional.

\section{METODE PELAKSANAAN KEGIATAN}

Kegiatan pelatihan pemanfaatan literasi informasi e-wakaf merupakan Program Kemitraan Masyarakat (PKM) berdasarkan permasalahan mitra. Mitra dalam PKM ini ada 2 (dua), yaitu (1). Pejabat Pembuat Akta Ikrar Wakaf (PPAIW) KUA, dan (2). Penyelenggara Syariah Kementerian Agama Kota Semarang. Metode pelaksanaan kegiatan pelatihan dan pemanfaatan literasi komputer dan informasi e-wakaf adalah melalui ceramah dan praktikum secara langsung di laboratorium komputer menggunakan sistem aplikasi e-Wakaf. Dalam pelatihan dan pemanfaat literasi komputer dan informasi ini diikuti oleh 35 peserta yang terdiri dari 16 orang peserta adalah PPAIW KUA, 16 orang peserta Penyuluh Agama Islam PNS/Non PNS, dan 3 orang peserta dari Penyelenggara Syariah Kementerian Agama Kota Semarang. Pelatihan dan pemanfaataan literasi komputer dan informasi ini diharapkan dapat menjadi solusi dari permasalahan yang dihadapi oleh pihak mitra, yaitu:

1) Paradigma lama dalam pengelolaan wakaf, dimana aspek legalitas formal belum menjadi unsur penting dalam pengamanan harta benda wakaf. KUA yang memiliki tugas pembinaan perwakafan di tingkat kecamatan belum sepenuhnya membudayakan tertib administrasi (pencatatan), automasi dan integrasi proses pengelolaan data administrasif wakaf.

2) Data administratif wakaf masih terpisah-pisah dalam berbagai simpanan sehingga tidak efektif dan efisien dalam pengelolaan maupun penyajian informasi.

3) Dalam banyak hal, muncul berbagai kasus sengketa tanah-tanah wakaf yang disebabkan oleh beberapa faktor, diantaranya adalah minimnya bukti-bukti administratif Negara sebagai pelindung hukum.

4) Belum terbangunnya sistem terpadu dalam pengelolaan dan pengembangan harta benda wakaf. 
Dari permasalahan mitra yang teridentifikasi kemudian ditawarkan suatu metode penyelesaian masalah dengan menggunakan bantuan sistem aplikasi berbasis komputer e-Wakaf. Untuk hasil optimal penguasaan sistem aplikasi e-Wakaf peserta dibekali buku panduan penggunaan sistem aplikasi e-Wakaf. Dengan pendekatan ceramah dan praktikum laboratorium komputer diharapkan peserta mampu mengoperasikan komputer dan aplikasinya secara efektif dan mampu memanfaatkan dan menyajikan informasi secara efisien.

\section{HASIL DAN PEMBAHASAN}

\subsection{Literasi Komputer}

Literasi, secara sederhana dapat diartikan melek aksara atau keberaksaraan. Secara luas makna keberaksaraan bukan lagi bermakna tunggal melainkan mengandung beragam arti (multi literacies), misalnya literasi komputer (computer literacy), literasi teknologi (technology literacy), literasi informasi (information literacy) dan lain-lain. Literasi dapat diartikan melek komputer, melek teknologi, melek informasi dan lain-lain seperti berpikir kritis, peka terhadap lingkungan, bahkan juga peka terhadap politik (Naibaho, 2007). Literasi Komputer adalah pengetahuan dan kemampuan untuk menggunakan komputer dan teknologi secara efisien (Cambridge English Dictionary, 2018). Literasi komputer juga dapat merujuk kepada tingkat kenyamanan seseorang yang terbiasa menggunakan program komputer dan aplikasi komputer (Masboedi, 2009). Dengan demikian Literasi komputer adalah bertujuan untuk membantu peserta mendapatkan hasil maksimal dari penggunaan Komputer (TIK) secara nyaman dan kemudian menjadi terbiasa menggunakan program dan aplikasi untuk mengolah dan merekayasa informasi. Dengan literasi komputer seseorang mempunyai pengetahuan dan kemampuan untuk menggunakan Komputer (TIK) secara efisien, atau dengan kata lain seseorang memiliki ketrampilan, pengetahuan dan tidak gaptek (kesulitan) Komputer (TIK) sehingga membantu dan memudahkan dalam menyelesaikan tugas sehari-hari.

\subsection{Literasi Informasi}

Paul G. Zurkowski dalam (Pattah, 2014) literasi informasi adalah teknik dan kemampuan untuk memanfaatkan berbagai alat-alat informasi serta sumber-sumber primer untuk memecahkan masalah mereka. Literasi informasi disebut juga melek informasi (Lasa H.S., 2009), yakni kesadaran akan kebutuhan informasi seseorang. Sedangkan Utami Wisnu Wardhani dalam artikel perpustakaan (2017) menjabarkan bahwa literasi informasi merupkan serangkaian kemampuan yang dibutuhkan seseorang secara sadar dengan mengidentifikasi, menemukan dan mengevaluasi kapan informasi itu dibutuhkan dan tahu bagaimana cara mendapatkanya (Utami Wisnu Wardhani, 2017), dengan demikian seseorang mampu menempatkan dan menggunakan informasi yang dibutuhkan secara efektif untuk isu atau masalah yang sedang dihadapi. Sedangkan manfaat literasi informasi bagi masyarakat luas adalah untuk mempermudah dalam menemukan informasi sesuai kebutuhan dan menggunakan informasi tersebut secara efektif. Dengan kesadaran ini akan mendukung perkembangan proses pembelajaran sepanjang hayat/long life education.

\subsection{Pemanfaatan literasi komputer dan informasi menggunakan Aplikasi E-Wakaf}

Aplikasi e-Wakaf dikembangkan berdasarkan perencanaan strategis jangka panjang yang kemudian rencana tersebut di transformasikan sebagai kumpulan strategi (Strategy set information) berupa rencana strategis sumber daya informasi sebagai kumpulan strategi organisasi (organizational strategi set), yang kemudian diteruskan ke dalam rencana jasa informasi melaui kumpulan strategi SIM (MIS strategy) yang terdiri dari sejumlah tujuan, kendala dan strategi (Raymond McLeod and George Schell, 2006) (Sharda et al., 2014). Aplikasi e-wakaf menggunakan teknologi Remote Sensing Sistem Informasi Geografis (GIS) yang dapat diakses secara online menggunakan peta dasar dan digunakan untuk mengelola (menghimpun, menyimpan, memproses), mengontrol dan mengendalikan (Priyono and Rahayu, 2003) aset wakaf melalui penginderaan jauh keruangan, dan menghasilkan informasi baik berupa laporan perkembangan dan persebaran aset 
wakaf, dokumen W1-W7 dan F7, grafik, gambar peta dan keluaran lainnya yang relevan termasuk menghasilkan peta tematik aset wakaf.

Pelatihan menggunakan aplikasi e-Wakaf dimulai dari menyiapkan kebutuhan aplikasi, menjalankan aplikasi, penyiapan data-data aset wakaf, entry data dan proses penggalian dan penyampaian laporan-laporan serta kontrol kendali objek wakaf menggunakan data spasial dan atribut Geographical Information System (GIS).
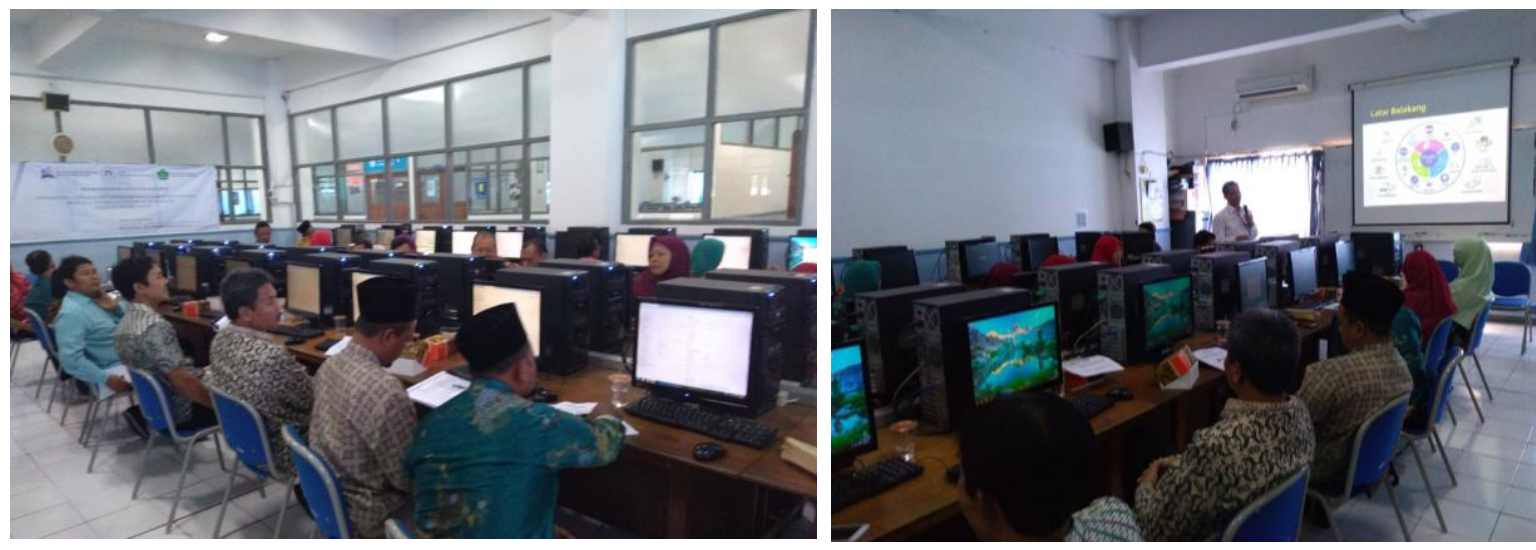

Gambar 1. Pelaksanaan kegiatan pelatihan dan pemanfaatan literasi komputer dan informasi

Dalam pelatihan ini penyampaian materi dilakukan dengan metode ceramah untuk pengayaan pengetahuan tentang pengelolaan wakaf oleh narasumber dari Kantor Kementerian Agama Kota Semarang dan praktikum penggunaan langsung sistem aplikasi e-Wakaf siap pakai oleh tim pengabdian program kemitraan masyarakat. Di laboratorium komputer peserta menjalankan aplikasi e-Wakaf untuk memasukkan data-data administratif wakaf sampai dengan mencetak keluaran berupa laporan dan keluaran lainya. Metode Diskusi dan tanya jawab dilakukan pada akhir pelatihan. Dikusi dan tanya jawab digunakan sebagai umpan balik hasil dari pelatihan mengenai materi yang telah dipaparkan.

\subsubsection{Menjalankan Aplikasi E-Wakaf}

Untuk menjalankan Sistem Informasi Geografis Aset Wakaf melalui browser seperti Internet Explorer, Google Chrome atau Mozilla Firefox dan diakses melalui sambungan internet di halaman http://www.e-wakaf.info, tampilan aplikasi akan segera muncul dilayar dan tampak seperti gambar 1. 


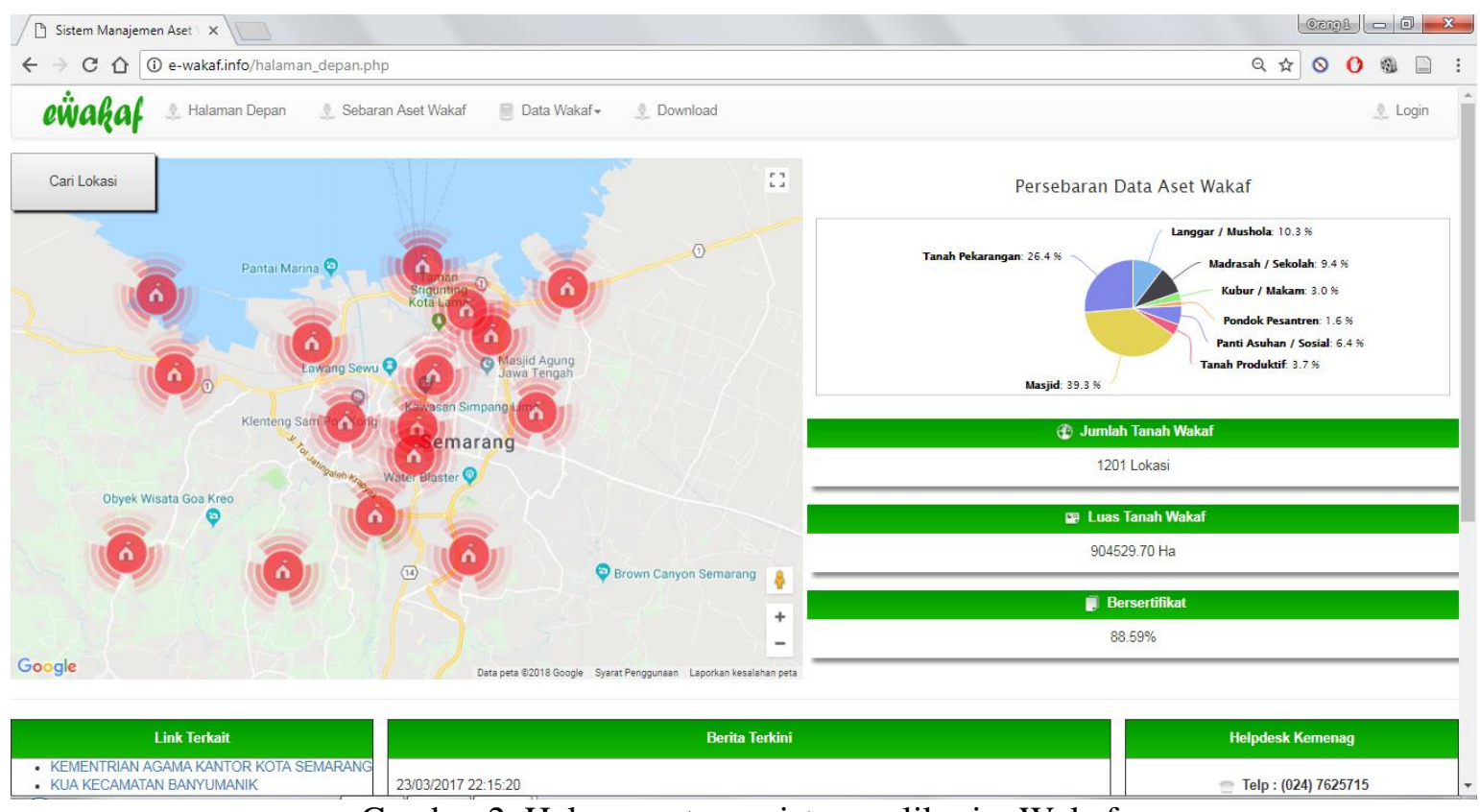

Gambar 2. Halaman utama sistem aplikasi e-Wakaf

Halaman utama (home) disediakan untuk informasi publik. Informasi publik dapat diakses oleh masyarakat umum yang menginginkan informasi terkini tentang data-data dan informasi mengenai wakaf kota Semarang. Halaman utama ini juga dapat digunakan sebagai bentuk tanggung jawab Kementerian Agama Kantor Kota Semarang kepada stokeholder dalam upaya untuk mengembangkan penyelenggaraan kepemerintahan yang berbasis elektronik (e-Goverment) dalam rangka transparansi, akuntabilitas dan meningkatkan kualitas layanan publik secara efektif dan efisien (Good Governant).

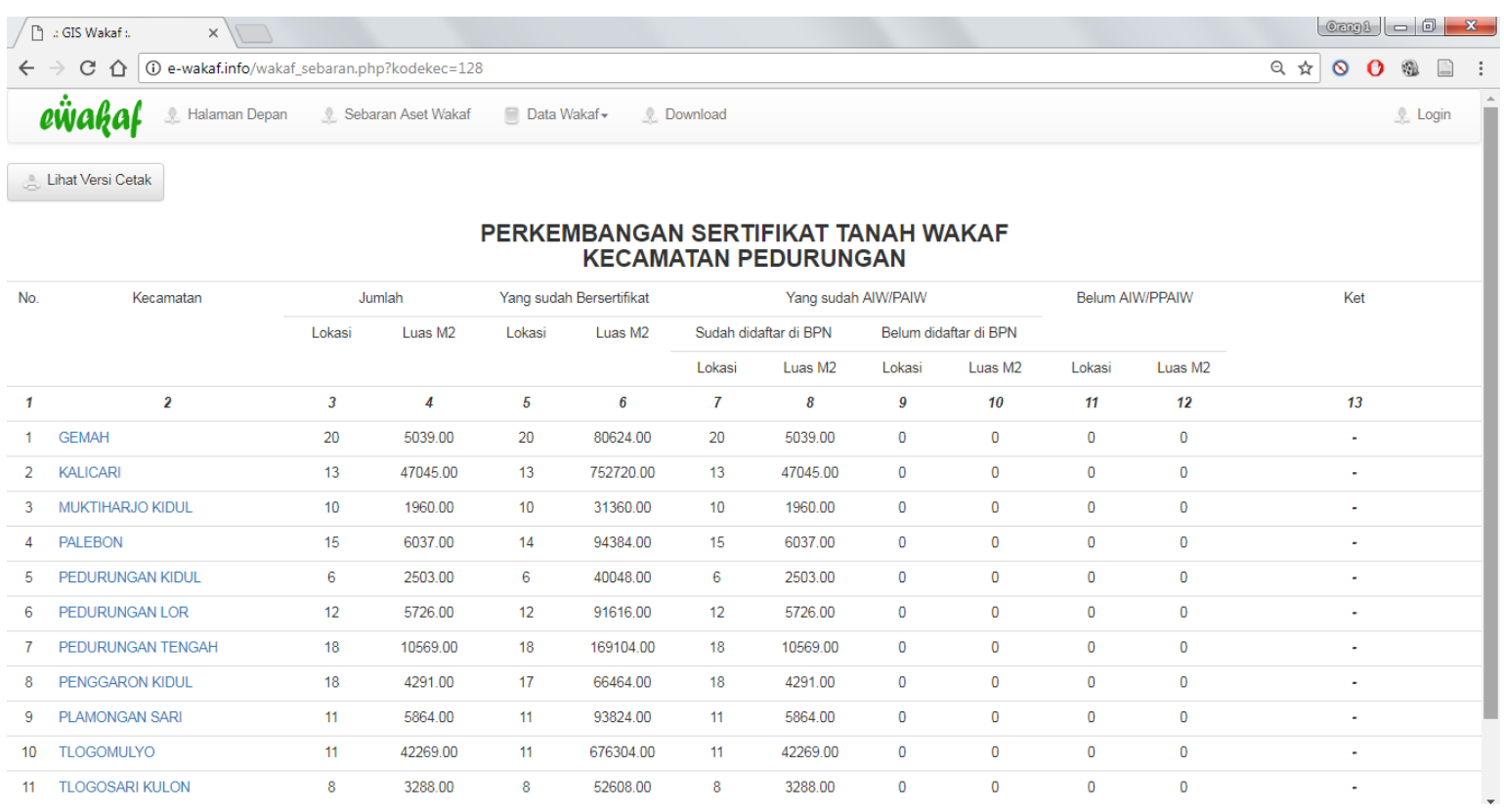

Gambar 3. Contoh informasi publik sebaran aset wakaf di Kecamatan Pedurungan

\subsubsection{Keamanan Sistem E-Wakaf}

User dan password berfungsi sebagai bentuk keamanan sistem. Terdapat tiga jenis user yang dapat mengakses aplikasi e-Wakaf. Akses level user pada aplikasi ini terbagi menjadi tiga sesuai kewenangan masing-masing:

1. User Administrator : memiliki hak akses tak terbatas pada aplikasi ini. User ini adalah pengelola level atas Penyelenggara Syari'ah Kementerian Agama Kantor Kota Semarang. 
2. User untuk PPAIW/KUA: memiliki akses pada modul-modul aplikasi tertentu sebagai kewenangannya.

3. User untuk Nadzir: memiliki akses terbatas dan hanya untuk melengkapi atribut nazhir dan aset wakaf yang dikelolanya.

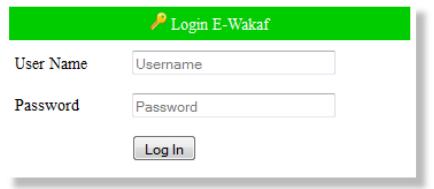

Gambar 4. Form login sistem e-Wakaf

\subsubsection{Akta Ikrar Wakaf sebagai Data Dasar Administratif Wakaf}

Pengelolaan Harta Benda Wakaf untuk mencapai tujuan wakaf dan Kepala KUA sebagai Pejabat Pembuat Ikrar Wakaf (PPAIW) harus memenuhi kehendak wakif (Departemen Agama Republik Indonesia, 2008). Masalah utama wakaf berkaitan dengan pengelolaan wakaf seperti: pencatatan, pendaftaran, pembuatan AIW, pengelola/nadzir (perorangan/ ditunjuk, organisai, dan badan hukum), dan dokumentasi daftar akta ikrar wakaf menurut bentuk W.4, sampai dengan mengajukan permohonan pendaftaran Tanah Wakaf kepada Kepala BPN, perlu dikelola dan administrasikan dengan baik sebagai pengaman dari hilangnya sejumlah aset wakaf, penyalahgunaan tanah wakaf dan kendala-kendala lain karena tidak jelasnya status tanah wakaf dapat diminimalisir.

Pendataan wakaf dapat dilakukan dengan mudah oleh pengguna sesuai dengan kewenanganya melalui aplikasi e-Wakaf dengan menu-menu aplikasi yang telah disediakan.

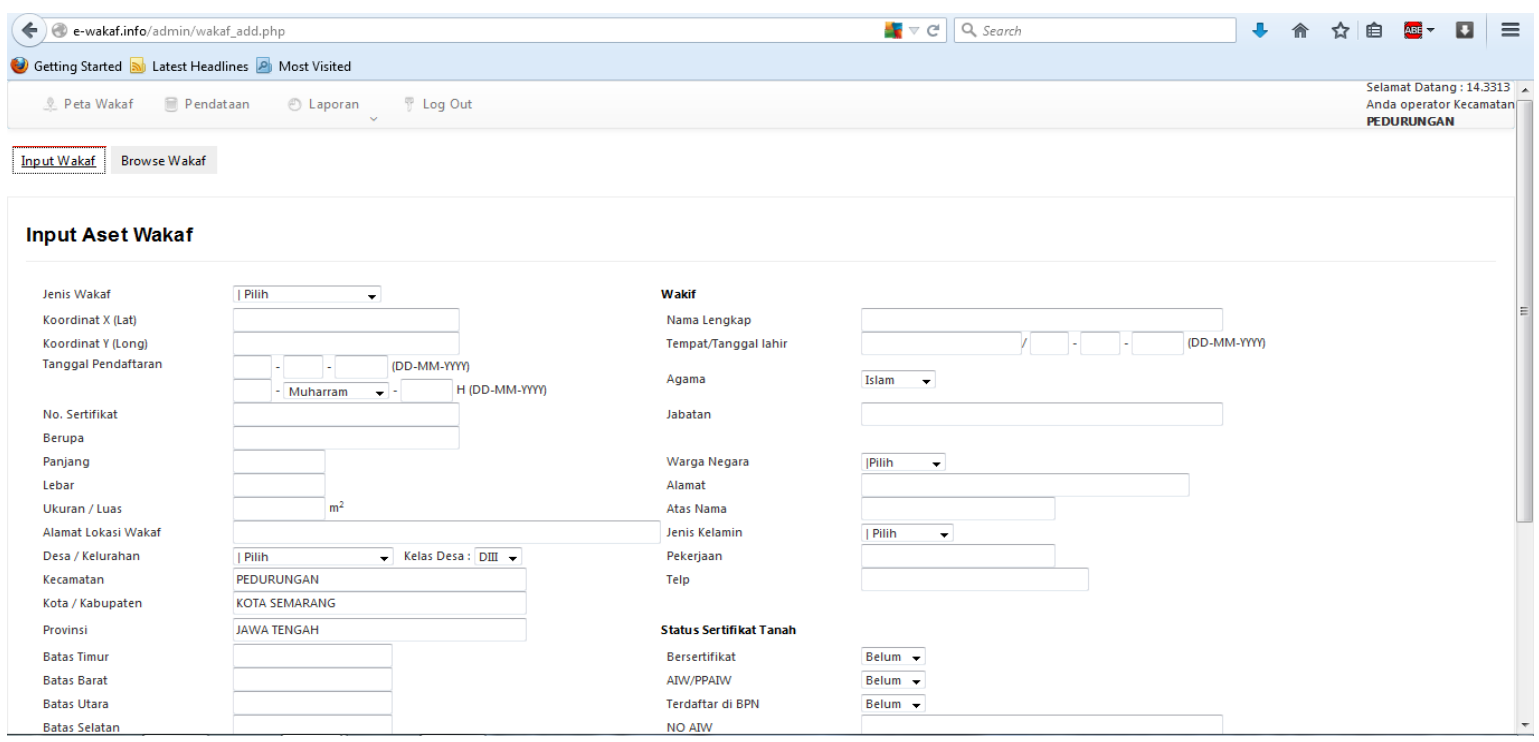

Gambar 5. Pencatatan data wakaf

Pencatatan data wakaf berdasarkan atribut-atribut yang akan dicetak pada akta ikrar wakaf, sehingga setelah perekaman data dapat langsung digunakan untuk mencetak akta ikrar wakaf untuk ditanda-tangani oleh PPAIW. 


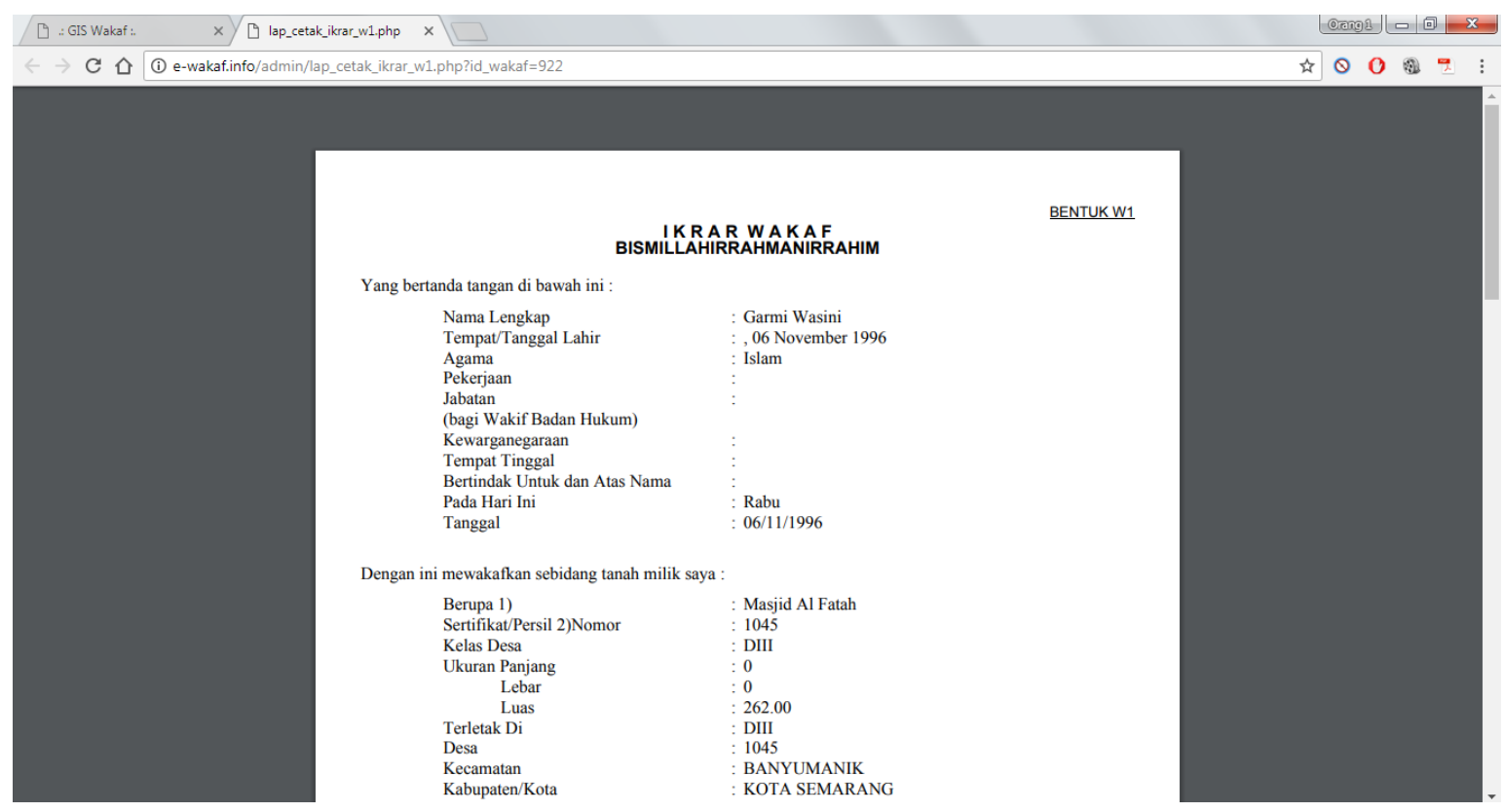

Gambar 6. Akta Ikrar Wakaf W.1

\subsubsection{Laporan dan Informasi Wakaf}

Dari data-data yang telah dicatat dan direkam, kemudian diolah dan dikelompokkan sedemikian rupa dan disajikan dalam bentuk laporan dan informasi-informasi yang dibutuhkan sesuai dengan kepentingannya baik PPAIW KUA, Penyelenggra Syari'ah maupun informasi publik masyarakat umum.

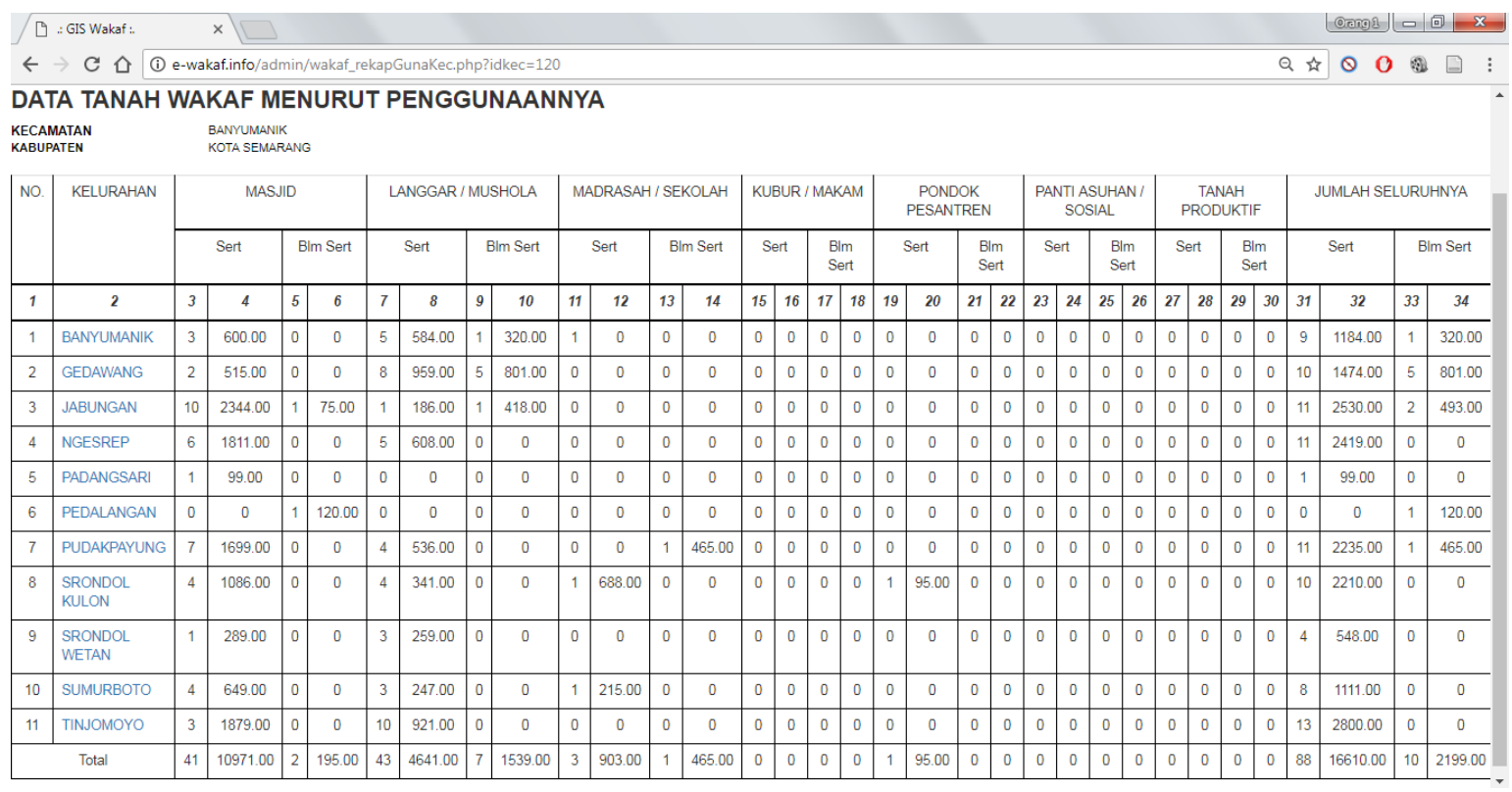

Gambar 7. Laporan perkembangan tanah wakaf

\section{KESIMPULAN}

Pelaksanaan kegiatan pelatihan dan pemanfaatan literasi komputer dan informasi e-Wakaf secara umum dapat disimpulkan bahwa dari 35 peserta pelatihan yang terdiri dari 16 orang peserta dari PPAIW KUA, 16 orang peserta dari Penyuluh Agama Islam PNS/Non PNS dan 3 orang peserta dari Penyelengara Syariah dapat mengikuti seluruh materi yang disampaikan oleh 
narasumber dan dapat melakukan kegiatan praktikum di laboratorium menggunakan aplikasi eWakaf secara mandiri dengan tertib, lancar, dan penuh antusias sampai dengan akhir kegiatan pelatihan ditutup.

Indikator keberhasilan yang dicapai juga dapat diidentifikasi dari banyaknya data wakaf yang telah dimasukkan oleh peserta dan tercatat dalam rekaman baris data/record sistem e-Wakaf (http://e-wakaf.info) sebanyak 1.201 lokasi tanah wakaf dengan luas mencapai 904.529,70 Ha. Persebaran dan perkembangan wakaf dapat dirinci penggunaannya sebagai berikut, untuk penggunaan Masjid sebanyak 466 lokasi (38,8\%), Langgar/Mushola sebanyak 514 lokasi (42,8\%), Madrasah/Sekolah sebanyak 122 lokasi (10,1\%), Pondok Pesantren sebanyak 29 (2,4\%), Panti Asuhan/Sosial sebanyak 15 lokasi (1,2\%), Tanah Pekarangan 43 lokasi (3,6\%), Tanah Produktif 1 $(0,1 \%)$ dan Kubur/Makam 12 lokasi (1,2\%). Berdasarkan luasnya Masjid (39,3\%), Langgar/Mushola (10,3\%), Madrasah/Sekolah (9,4\%), Pondok Pesantren (1,6\%), Panti Asuhan/Sosial (6,4\%), Tanah Pekarangan (26,4\%), Tanah Produktif (3,7\%) dan Kubur/Makam (3,0\%) ("Sistem Manajemen Aset Wakaf," n.d.).

Dengan penggunaan e-Wakaf diharapkan pengelolaan administratif wakaf berjalan dengan tertib dan PPAIW KUA memiliki data wakaf yang akurat dan kredibel. Disamping itu PPAIW memiliki performa yang ideal dan memiliki kemampuan profesional dalam mencatat dan mengelola administrasi harta benda wakaf di lingkungan kerjanya dan dapat meningkatkan kualitas pelayanan prima kepada masyarakat.

\section{UCAPAN TERIMA KASIH}

Amiq Fahmi dan Edi Sugiarto adalah dosen Fakultas Ilmu Komputer Universitas Dian Nuswantoro Semarang, yang pada saat ini sedang melaksanakan Program Kemitraan Masyarakat dengan judul "Peningkatan Literasi Komputer Dan Informasi Bagi Penyuluh Agama, PPAIW KUA, Dan Penyelenggara Syariah Dalam Pengelolaan Aset Wakaf". Ucapan terimakasih disampaikan kepada 1). Kantor Urusan Agama dan Penyelenggara Syariah Kementerian Agama Kantor Kota Semarang yang telah bersedia menjadi mitra dalam kegiatan ini, 2). Kementerian Riset, Teknologi dan Pendidikan Tinggi Republik Indonesia, yang telah memberikan dukungan keuangan melalui Program Kemitraan Masyarakat Tahun Anggaran 2018 yang dituangkan dalam surat perjanjian penugasan dalam rangka pelaksanaan program pengabdian masyarakat LP2M Universitas Dian Nuswantoro Nomor: 053/A.38-04/UDN-09/II/2018.

\section{DAFTAR PUSTAKA}

Cambridge English Dictionary, 2018. computer-literacy Meaning in the Cambridge English Dictionary. Camb. Univ. Press.

Departemen Agama Republik Indonesia, 2008. Panduan pemberdayaan tanah wakaf produktif strategis di Indonesia. Direktorat Pemberdayaan Wakaf, Direktorat Jenderal Bimbingan Masyarakat Islam, Departemen Agma RI, Jakarta.

Fahmi, A., Sugiarto, E., 2017. Sistem Informasi Geografis E-wakaf sebagai Model Pendukung Keputusan Pemberdayaan Wakaf Produktif. IKRAITH-Inform. 1, 87-93.

Fahmi, A., Sugiarto, E., 2016. Sistem Informasi Geografis Untuk Pengelolaan Dan Monitoring Persebaran Aset Wakaf. Techno.Com 15, 327-334.

Fahmi, A., Sugiarto, E., 2015. Aplikasi Sistem Informasi Geografis Manajemen Aset Wakaf. Pros. SNATIF 357-364.

Kementerian Agama Republik Indonesia, Direktorat Jenderal Bimbingan Masyarakat Islam, Direktorat Pemberdayaan Wakaf, 2013. Standar Pelayanan Wakaf Bagi Pejabat Pembuat Akta Ikrar Wakaf (PPAIW). Kementerian Agama Republik Indonesia.

Lasa H.S., 2009. Kamus kepustakawanan Indonesia, Cet. 1. ed. Pustaka Book Publisher, Yogyakarta.

Masboedi, 2009. Literasi Komputer. My Buddy.

Naibaho, K., 2007. Menciptakan Generasi Literat Melalui Perpustakaan [WWW Document]. Visi Pustaka. URL http://eprints.rclis.org/12549/ (accessed 5.26.18). 
Pattah, S.H., 2014. Literasi informasi: peningkatan kompetensi informasi dalam proses pembelajaran. Khizanah Al-Hikmah J. Ilmu Perpust. Inf. Dan Kearsipan 2, 108-119.

Priyono, S.B., Rahayu, S., 2003. Aplikasi Penginderaan Jauh Dan Sistem Informasi Geografis (SIG) Untuk Perencanaan Pengembangan Tambak Biocrete. J. Perikan. Univ. Gadjah Mada 5, 32-38.

Raymond McLeod, George Schell, 2006. Management Information Systems (10th Edition). Prentice-Hall, Inc. Upper Saddle River, NJ, USA.

Republik Indonesia, 2004. Undang-Undang Nomor 41 Tahun 2004 Tentang Wakaf.

Sharda, R., Delen, D., Turban, E., Aronson, J., Liang, T.P., 2014. Businesss Intelligence and Analytics: Systems for Decision Support. Prentice Hall London.

Sistem Manajemen Aset Wakaf [WWW Document], n.d. URL http://ewakaf.info/halaman_depan.php (accessed 5.27.18).

Utami Wisnu Wardhani, 2017. Literasi Informasi di Era Digital - Dinas Kearsipan dan Perpustakaan Prov. Kep. Bangka Belitung. Artik. Perpust. 